\title{
KINETICS OF STRUCTURAL TRANSFORMATIONS AT PORES FORMATION DURING HIGH-TEMPERATURE TREATMENT OF FOAM GLASS
}

\author{
Sergey V. Fedosov " ${ }^{1}$ Maksim O. Bakanov ${ }^{2}$, Sergey N. Nikishov ${ }^{1,2}$ \\ ${ }^{1}$ Ivanovo State Politechnical University, Ivanovo, RUSSIA \\ ${ }^{2}$ Ivanovo Fire Rescue Academy of State Firefighting Service of Ministry of Russian Federation for Civil Defense, \\ Emergencies and Elimination of Consequences of Natural Disasters, Ivanovo, RUSSIA
}

\begin{abstract}
Annotation: The work shows the key points used in the simulation of pores formation and growth in the foam glass structure. Pore is represented as a separate radius growth center with the outer boundary of a spherical shape and with a specified value of the initial radius surrounded by a finite volume of molten glass that is a part of foam glass charge stock. Solution of three-dimensional problem is reduced to one-dimensional setting in spherical coordinates. The presented model takes into consideration kinetics of pores radius growth, taking into account the influence of glass viscosity and surface tension, as well as the effect of moving (stretching) glass cladding when pores radius increases.
\end{abstract}

Keywords: foam glass, separate pore, mathematic simulation, glass cladding, surface tension, viscosity

\section{КИНЕТИКА СТРУКТУРНЫХ ПРЕВРАЩЕНИЙ ПРИ ФОРМИРОВАНИИ ПОР В ПРОЦЕССЕ ВЫСОКОТЕМПЕРАТУРНОЙ ОБРАБОТКИ ПЕНОСТЕКЛА}

\author{
С.В. Федосов ${ }^{1}$, М.О. Баканов ${ }^{2}$, С.Н. Никишов ${ }^{1,2}$ \\ ${ }^{1}$ Ивановский государственный политехнический университет, г. Иваново, РОССИЯ \\ ${ }^{2}$ Ивановская пожарно-спасательная академия ГПС МЧС России, г. Иваново, РОССИЯ
}

\begin{abstract}
Аннотация: В работе показаны ключевые моменты, применяемые при моделировании процесса формирования и роста пор в структуре пеностекла. Пора представляется как единичный центр роста радиуса с внешней границей сферической формы и с заданным значением начального радиуса, окруженный конечным объемом расплава стекла, входящего в состав пеностекольной шихты. Решение трехмерной задачи сведено к одномерной постановке в сферических координатах. Представленная модель учитывает кинетику роста радиуса пор с учетом влияния вязкости стекла и поверхностного натяжения, а также эффект движущейся (растягивающейся) стеклянной оболочки при увеличении радиуса поры.
\end{abstract}

Ключевые слова: пеностекло, единичная пора, математическое моделирование, стеклянная оболочка, поверхностное натяжение, вязкость

\section{INTRODUCTION}

Currently, manufacturers of heat insulating materials have to adapt to the dynamically changing market conditions, since consumers start to pay interest to the materials with high structural performance and materials with good heat and sound insulation properties.
In this regard, such heat insulating material as foam glass [15] gains growing popularity. Foam glass production technology is associated with thermal treatment of raw material mixture (foam glass charge stock), which involves consumption of a significant amount of electrical power [2, 5], due to which the finished product cost is higher than for example, in case of expanded-clay con- 
crete, foamed concrete, autoclaved aerated concrete, pumice stone concrete, sawdust concrete and other heat insulating materials.

It is required to pay attention to scheduling thermal treatment processes in order to reduce the production cost of foam glass. Knowledge of the heating processes peculiarities, foaming and annealing of foam glass charge stock will enable to adjust the material quality, energy consumption and production areas by adjusting the thermal treatment modes and sizes of process equipment [13].

It is worth noting that one of the main factors in the foam glass technology is to obtain the material with uniformly distributed pores throughout the volume. Foam glass porous structure formation is very important, because physical and chemical properties of finished product are formed during this process $[3,6]$.

Currently, foam glass powder production method is the most widespread because it enables to receive the finished product with different characteristics depending on composition and ratio of raw feedstock and gas developing agent [12].

For receive foam glass with the use of powder method the mixture of crushed glass and gas developing agent is subjected to thermal treatment at the temperatures above the glass softening point and gas developing agent decomposition. During the heating the glass particles are sintered together forming the pores, which gas developing agent particles get into [16]. Thus, the pores radius growth centers are formed. External boundaries of pores radius growth centers must be increased in order to produce foam glass with low density and with large volumetric weight. Due to similar processes the thickness of formed interporous glassy partitions decreases [11]. Sintering and pores initial formation is shown schematically in Fig. 1.

Thermal decomposition of gas developing agent and increase in the gas stage content in the foam glass charge stock determines the pore-forming potential of the whole charge stock.

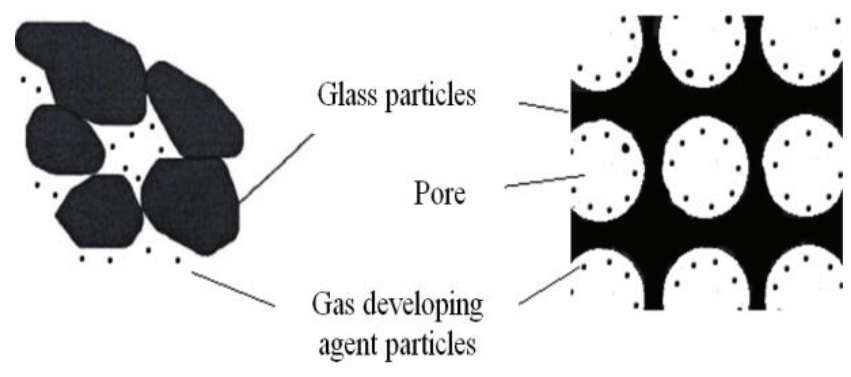

Figure 1. Pores initial formation during sintering of glass/gas developing agent mixture.

Equilibrium state of gas phase pressure inside a pore and surface tension of molten glass on its boundaries contributes to formation of a uniform porous structure throughout the material volume. Gas developing agent activation leading to increase in gas phase pressure and as a consequence the volume inside a pore constitutes inertial potential of call growth. Gas generation depends on the bulk transfer of chemically and physically dissolved oxygen in the glass volume around the pore surface [7], during its interaction with carbon the $\mathrm{CO}$ or $\mathrm{CO}_{2}$, the gas, is formed. The most developed models describing the pores growth or shrinkage in the glass melt consider only separate pore in an infinite glass melt with a spherical shape. Obvious conclusion is that simulation of pore growth in foam glass charge stock taking into consideration limitless glass melt surrounding the latter one does not provide adequate dependencies and perceptions of structural transformations in the process of foam glass charge stock thermal treatment.

The works $[20,22]$ demonstrate that the approaches in which assumptions about infinite melt of foam glass charge stock surrounding a separate pore are adopted, can be applied to simulate the structural transformations only at the initial stages of pores radius growth with the sizes about 10 microns. However, over time, in terms of pores radius growth, the latter ones start to interact with each other, thereby forming a porous matrix (Fig. 2). 


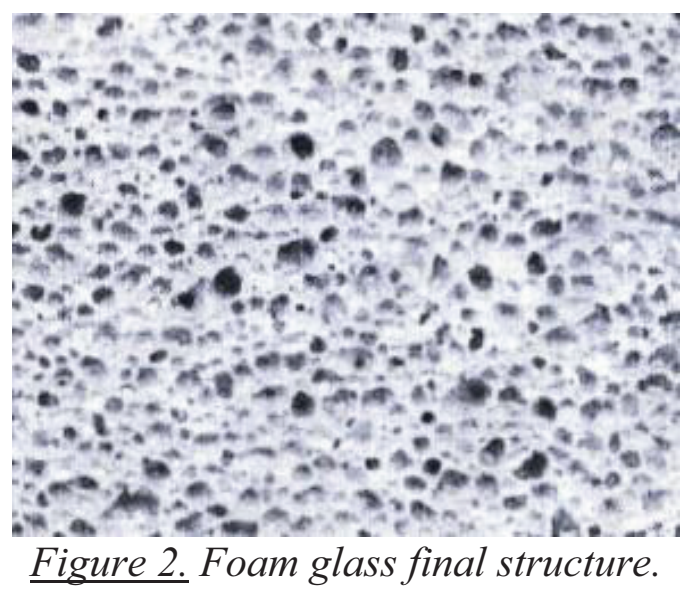

\section{RESEARCH METHODS}

Simulation of separate pore radius growth taking into consideration infinite melt glass volume surrounding a pore is non-rational because with this assumption the cellular structure of the target material and interaction of neighboring pores is not taken into account. Cellular structure of foam glass shows that each pore cladding is surrounded by a finite volume within the limits of its glass partitions. Pores shape in the finished foam glass is more polygonal than spherical. This deviation from spherical nature dramatically increases the mathematic simulation complexity.

However, taking pores spherical shape during mathematic simulation with small volume-equal partitions, as shown in Figure 3, instead of polygons, permissible error in this case does not exceed $5 \%$. This ratio was determined by comparing the models with the structure in the pores form with systems of closely spaced pores [19]. Figure 3 demonstrates the model of spherical pores in foam glass where spherical pores (cells) and glass claddings around them are displayed in such a way having described a single unit cell then the rest of the cells can be similarly described.

In developing the model we consider a separate spherical pore with an initial radius surrounded by a finite volume of foam glass charge stock melt. This allows to reduce the three dimensional problem to one-dimensional problem in spherical coordinates.

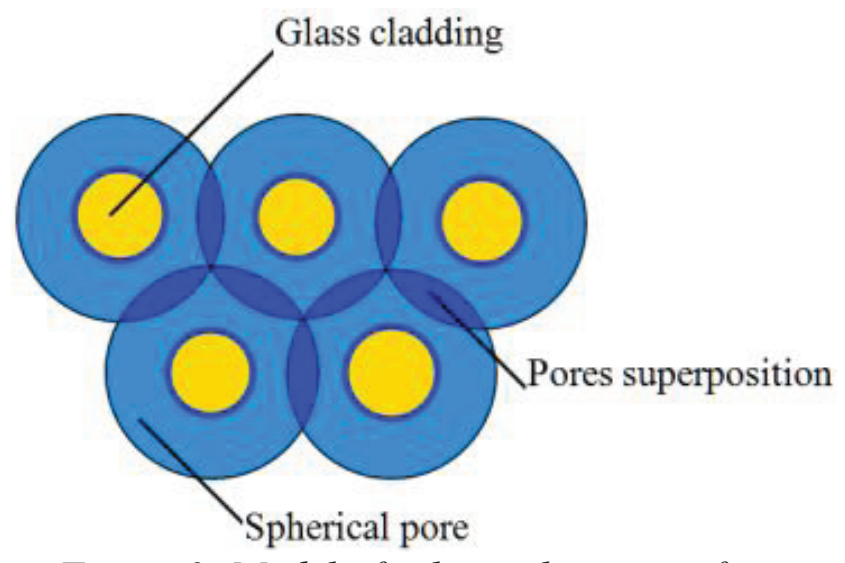

Figure 3. Model of spherical pores in foam glass.

Important aspect of pores growth simulation is the influence of pore radius increasing on the molten glass volume. Taking into consideration the spherical shape of pores, surrounded by glass cladding, the cladding thickness decreases with pore radius increasing, since constant volume of the mold for foaming is assumed. Glass particles melt, stick together with each other and form voids at the initial stage. With increasing temperature, first shrinkage of the charge stock as a result of transition from solid to molten state takes place, and then gas developing agent inside the voids starts to activate, and the internal pressure starts to increase thereby forming a pore. Shrinkage (decrease of the geometric dimensions) occurs as long as the pressure generated inside the forming pore is equal to the pressure on the surface. Growth of the produced gas concentration gradually leads to increasing in internal pressure and increasing in the pore radius. This effect is shown schematically in Fig. 4.

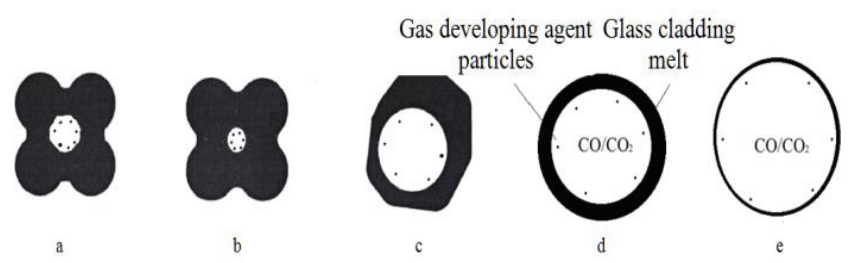

Figure 4. Dynamics of change of the radius of separate pores and melt glass cladding volume ( $a$-sticking of particles and the pores formation, $b$-pore reduction; $c$-glass cladding formation; $d$-pore growth; $e$-decrease of glass cladding volume). 
Analysis of the existing mathematical models describing the formation of foam glass porous structure $[14,17]$ has shown that it is required to develop such a model that will enable to describe the foaming process not only at the micro level (separate pore change, but at the macro level as well (size change of the total charge stock volume), since it is required to resolve the boundary value problem with moving boundaries for the ability to describe the temperature fields in foam glass charge stock, and without knowledge of the law regarding changing the geometry of the charge stock is almost impossible. Simulation of temperature fields' distribution in charge stock is one of the key issues in improving the foam glass production technology. In this work we didn't state the aim to describe influence of the law regarding pore size change on the solution of equations on heat conductivity factor in charge stock. However, we should not keep silence about the fact. Returning to the question of bubble growth simulation, it should be noted that ideally, the model should consider not only described by us below effects of glass viscosity and surface tension, but also the diffusion processes as the mass transfer of the molten glass determines the laws of the porous structure of foam glass formation.

\section{BASIC PART}

Complexity of pores formation in the foam glass during its production significantly complicates the analytical solution for such problems. Thus, it's required to simplify certain conditions or even neglect them, so let's take a number of assumptions.

1. Melt glass around a pore is taken as incompressible

$$
\frac{d \rho}{d t}=0
$$

while the glass density forming a part of foam glass charge stock - as constant at any point and time moment

$$
\nabla \rho=0 .
$$

2. Melt viscosity of foam glass charge stock will be taken as depending only on temperature and pressure.

3. We consider a separate pore of a completely spherical shape, therefore,

$$
v_{\theta}=v_{\varphi}=0 ; \frac{\partial}{\partial \theta}=\frac{\partial}{\partial \varphi}=0 \text {. }
$$

The assumption shows that cladding external boundary is the boundary between two pores of identical size, including its cladding.

4. Temperature is taken as constant for every small time interval, i.e. there is no temperature gradient in the area pore/glass cladding.

5. Spherical coordinates with the system origin of coordinates in the pore center are used (Fig. 5).

6. Despite the fact that external boundary of the considered pore cladding out of the glass melt is the boundary between the neighboring pores of identical size (Fig. 3) we assume that the external surface of separate pore (when $r=\mathrm{R}_{2}$ ) is impermeable to penetration of gaseous products that are generated as a result of thermal decomposition reaction of the gas developing agent in the neighboring pores.

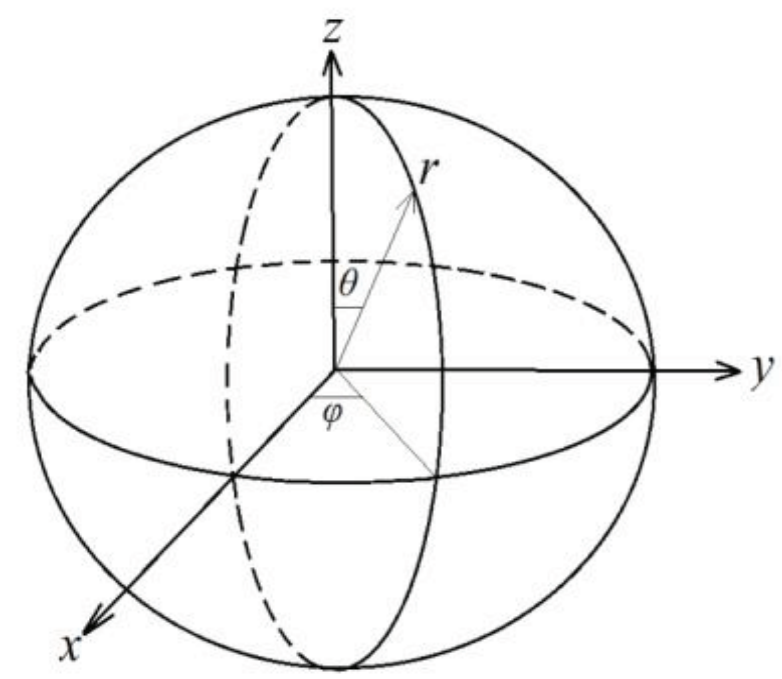

Figure 5. The coordinates system used for the considered pore. 
7. Glass melt behaves as a Newtonian fluid, i.e. viscosity, according to this definition, depends only on temperature and pressure, but not from movement rate.

Continuity equation for fluid in accordance with [4] can be written down as:

$$
\frac{\partial \rho}{\partial \mathrm{t}}=-(\nabla \cdot \mathrm{pv})
$$

where $\rho$ - fluid density $\left[\mathrm{kg} / \mathrm{m}^{3}\right], t$ - time $[\mathrm{sec}]$ and $\boldsymbol{v}$ - vector of the sustained mass flow rate $[\mathrm{m} / \mathrm{sec}]$. For incompressible fluid with constant density values, we get the following:

$$
(\nabla \cdot \boldsymbol{v})=0
$$

Spherical symmetry eliminates expression for directions $\theta$ and $\varphi$. At a constant glass density for the continuity equation at the glass phase we get:

$$
(\nabla \cdot \boldsymbol{v})=\frac{1}{r^{2}} \frac{\partial}{\partial r}\left(r^{2} v_{r}\right)=0,
$$

where $r$ - radial coordinate in spherical coordinates $[\mathrm{m}], v_{\mathrm{r}}-$ average fluid rate in $r$ direction $[\mathrm{m} / \mathrm{sec}]$.

Integration of equation (3) between the two boundaries $R_{1}$ and $R_{2}$, where $R_{1}$ is the pores inner radius [m] and $R_{2}$ is the outer radius [m], leads to:

$$
r^{2} v_{r}=\text { constant }=R_{1}^{2} v_{R_{1}} \leftrightarrow v_{r}=\frac{R_{1}^{2}}{r^{2}} v_{R_{1}},
$$

where $v_{R_{1}}$-pores radius growth rate $R_{1}$.

$$
v_{R_{1}}=\frac{d R_{1}}{d t} .
$$

Under the conditions that the pore has a spherical shape, the glass melt is a continuous medium that fills the space without voids and gaps, and, neglecting gravitational forces, the Navier - Stokes equation for incompressible viscous fluid is reduced to the following view [3]:

$$
\begin{gathered}
\rho\left[\frac{\partial v_{r}}{\partial t}+v_{r} \frac{\partial v_{r}}{\partial r}\right]= \\
-\frac{\partial p}{\partial r}-\frac{1}{r^{2}} \frac{\partial}{\partial r}\left(r^{2} \tau_{r r}\right)+\frac{\tau_{\theta \theta+} \tau_{\varphi \varphi}}{r}
\end{gathered}
$$

where $p$-pressure $[\mathrm{Pa}], \tau_{\mathrm{rr}}$ - radial component of the stress tensor in the $r$-direction $[\mathrm{Pa}], \tau_{\theta \theta}, \tau_{\varphi \varphi}-$ similar components of the stress tensor in the indicated directions $\theta$ and $\varphi$.

Assuming that the viscous fluid follows the Newton's law of viscous friction in its flow, $\tau_{\text {rr }}$ is obtained:

$$
\tau_{r r}=-\mu\left[2 \frac{\partial v_{r}}{\partial r}\right]+\frac{2}{3} \mu(\nabla \cdot \boldsymbol{v}),
$$

where $\mu$ - factor of fluid dynamic viscosity $[\mathrm{PA} \cdot \mathrm{s}]$. In terms of equation (2) we get:

$$
\tau_{r r}=-2 \mu \frac{\partial v_{r}}{\partial r}
$$

Similarly, the equations for $\tau_{\theta \theta}$ and $\tau_{\varphi \varphi}$ are converted to the following view:

$$
\begin{aligned}
\tau_{\theta \theta}= & -\mu\left[2\left(\frac{1}{r} \frac{\partial v_{\theta}}{\partial \theta}+\frac{v_{r}}{r}\right)\right]+ \\
& +\frac{2}{3} \mu(\nabla \cdot \boldsymbol{v})=-2 \mu \frac{v_{r}}{r} .
\end{aligned}
$$

$\tau_{\varphi \varphi}=-\mu\left[2\left(\frac{1}{r \sin \theta} \frac{\partial v_{\varphi}}{\partial \varphi}+\frac{v_{r}+v_{\theta} \operatorname{ctg} \theta}{r}\right)\right]+$ $+\frac{2}{3} \mu(\nabla \cdot v)=-2 \mu \frac{v_{r}}{r}$.

Then by putting the values of equations (8)-(10) in equation (5), we get:

$$
\begin{gathered}
\rho\left[\frac{\partial v_{r}}{\partial t}+v_{r} \frac{\partial v_{r}}{\partial r}\right]= \\
=-\frac{\partial p}{\partial r}-\frac{1}{r^{2}} \frac{\partial}{\partial r}\left(-2 \mu \frac{\partial v_{r}}{\partial r} \cdot r^{2}\right)-4 \mu \frac{v_{r}}{r^{2}} .
\end{gathered}
$$

Temperature range of the foam glass froth building varies from $600{ }^{\circ} \mathrm{C}$ to $900{ }^{\circ} \mathrm{C}$, and corresponding dynamic viscosity $\mu$ of foam glass charge stock modifies in the interval from $10^{8}$ to $10^{3}[\mathrm{~Pa}]$. Duration of foaming process makes from 0.5 to 1 hour, and the pore radius varies double-order from standard $10^{-5}$ to $10^{-3}[\mathrm{~m}]$. Reynolds Number:

$$
R \mathrm{e}=\frac{\rho v_{R} 2 R}{\mu}
$$


less than $10^{-9}$ throughout the total froth building mode $[8,9]$. In other words: for liquids with high viscosity two members of the left-hand side of equation (10) can be neglected since $v_{\text {r }}$ is very small and changes very slowly. Therefore, the thermal inertia $v_{r} \frac{\partial v_{r}}{\partial r}$ and the inertial member $\frac{\partial v_{r}}{\partial t}$ can be neglected. This simplifies equation (11) to the view:

$$
-\frac{\partial p}{\partial r}-\frac{1}{r^{2}} \frac{\partial}{\partial r}\left(-2 \mu \frac{\partial v_{r}}{\partial r} \cdot r^{2}\right)-4 \mu \frac{v_{r}}{r^{2}}=0 .
$$

Let's integrate equation (12), between $r=\mathrm{R}_{1}$ and $r=\mathrm{R}_{2}$ (glass cladding boundaries):

$$
\begin{gathered}
\int_{R_{1}}^{R_{2}}\left(-\frac{\partial p}{\partial r}\right) d r-\int_{R_{1}}^{R_{2}} \frac{1}{r^{2}} \frac{\partial}{\partial r}\left(-2 \mu \frac{\partial v_{r}}{\partial r} \cdot r^{2}\right) d r- \\
-\int_{R_{1}}^{R_{2}} 4 \mu \frac{v_{r}}{r^{2}} d r
\end{gathered}
$$

Let's integrate the first additive component:

$$
\int_{R_{1}}^{R_{2}}\left(-\frac{\partial p_{l}}{\partial r}\right) d r=p_{l}\left(R_{1}\right)-p_{l}\left(R_{2}\right)
$$

Let's integrate the second additive component by substituting equation (4):

$$
\begin{gathered}
\int_{R_{1}}^{R_{2}} \frac{1}{r^{2}} \frac{\partial}{\partial r}\left(-2 \mu \frac{\partial v_{r}}{\partial r} \cdot r^{2}\right) d r= \\
=\int_{R_{1}}^{R_{2}} \frac{1}{r^{2}} \frac{\partial}{\partial r}\left(\frac{4 \mu R_{1}^{2} v_{R_{1}}}{r}\right) d r= \\
=4 \mu R_{1}^{2} v_{R_{1}} \int_{R_{1}}^{R_{2}} \frac{1}{r^{4}} d r= \\
=\frac{4}{3} \mu R_{1}^{2} v_{R_{1}}\left[\frac{1}{R_{2}^{3}}-\frac{1}{R_{1}^{3}}\right]
\end{gathered}
$$

Let's integrate the third additive component by substituting equation (4):

$$
\begin{gathered}
\int_{R_{1}}^{R_{2}} 4 \mu \frac{v_{r}}{r^{2}} d r= \\
=4 \mu R_{1}^{2} v_{R_{1}} \int_{R_{1}}^{R_{2}} \frac{1}{r^{4}} d r=\frac{4}{3} \mu R_{1}^{2} v_{R_{1}}\left[\frac{1}{R_{2}^{3}}-\frac{1}{R_{1}^{3}}\right]
\end{gathered}
$$

Difference of equations (15) and (16) is equal to zero, so during integration of equation (12) between $\mathrm{R}_{1}$ and $\mathrm{R}_{2}$ we'll get:

$$
p_{l}\left(R_{1}\right)-p_{l}\left(R_{2}\right)=0,
$$

where $p_{\text {ж }}\left(\mathrm{R}_{1}\right)$ - fluid pressure at the inner radius $r=\mathrm{R}_{1}, \mathrm{p}_{\varkappa}\left(\mathrm{R}_{2}\right)$ - fluid pressure at the outer radius $r=\mathrm{R}_{2}$.

It should be noted that $R_{1}$ and $R_{2}$ are functions of time $\left(\mathrm{R}_{1}(\mathrm{t})\right.$ and $\left.\mathrm{R}_{2}(\mathrm{t})\right)$.

It is required to obtain the power balance in order to determine the values of various pressures, arising in the glass melt when $r=\mathrm{R}_{1}$ and $r=\mathrm{R}_{2}$, as well as surface tension effect on pores growth. In the absence of external powers on the fluid power balance can be obtained in accordance with Fig. 6.

As it has been already noted, the pore outer boundary at $r=\mathrm{R}_{2}$ is not the real outer boundary, but is the boundary of the glass cladding of the adjacent pore. Since one pore with its cladding is considered, initial pressure is the pressure applied to the entire system (pore + glass cladding).

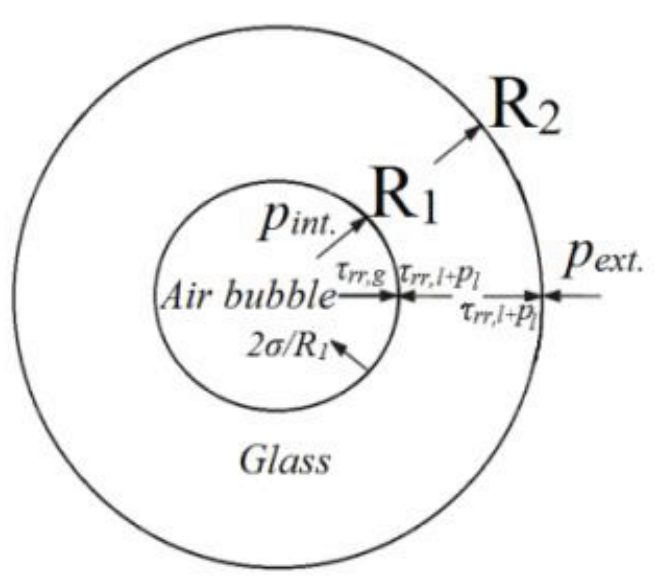

Figure 6. Power balance on the external and internal border of the glass cladding, arrows indicate the direction of forces.

Taking into account symmetry of the porous structure in the considered model of porous structure, the pressure acting on the glass cladding when $r=\mathrm{R}_{2}$ (pressure at the external boundary of glass melt), formed during gas formation reaction at thermal decomposition of gas developing agent in the foaming stages, we'll receive the balance of powers:

1) for $r=R_{1}$ : 


$$
\begin{aligned}
& p_{\text {int. }}+\tau_{r r, \Gamma}\left(R_{1}\right)= \\
= & p_{l}\left(R_{1}\right)+\tau_{r r, l}\left(R_{1}\right)+\frac{2 \sigma}{R_{1}},
\end{aligned}
$$

where $p_{\text {int. }}-$ gas pressure inside the pore [PA], $\sigma$ - surface tension factor $[\mathrm{N} / \mathrm{m}], \frac{2 \sigma}{\mathrm{R}_{1}}$ - voltage acting perpendicularly to the fluid surface due to surface tension.

2) for $r=R_{2}$ :

$$
p_{\text {ext. }}=p_{l}\left(R_{2}\right)+\tau_{r r, l}\left(R_{2}\right),
$$

where $p_{\text {ext. }}$ - pressure on external (outer) border of the glass melt $[\mathrm{Pa}]$.

Radial viscosity tension of gas phase $\tau_{r r}, g$ is very small compared to $\tau_{r r, l}$ of liquid phase and therefore it can be neglected. $\tau_{r r, l}$ is given by equation (7) therefore, by combining equations (8) and (4), we get the equation describing the stresses in the inner radius $\left(\mathrm{R}_{1}\right)$ and outer radius $\left(\mathrm{R}_{2}\right)$ :

$$
\begin{aligned}
& \tau_{r r, l}\left(R_{1}\right)=\frac{4 \mu}{R_{1}} \frac{d R_{1}}{d t} . \\
& \tau_{r r, \mathrm{l}}\left(R_{2}\right)=\frac{4 \mu}{R_{2}} \frac{d R_{2}}{d t} .
\end{aligned}
$$

From power balance and equations (17), we get:

$$
\begin{gathered}
p_{\text {int. }}-p_{\text {ext. }}-\frac{2 \sigma}{R_{1}}- \\
-4 \mu\left(\frac{d R_{1}}{d t} \frac{1}{R_{1}}-\frac{d R_{2}}{d t} \frac{1}{R_{2}}\right)=0 .
\end{gathered}
$$

Since the total volume of pore cladding glass melt $\left(V_{\varkappa}\right)$ is adopted by us as constant, $\mathrm{R}_{1}$ and $\mathrm{R}_{2}$ will be linked through the equation:

$$
V_{l}=\frac{4}{3} \pi\left(R_{2}^{3}-R_{1}^{3}\right)=\text { constant } .
$$

Thus:

$$
R_{2}=\left[\frac{V_{l}}{\frac{4}{3} \pi}+R_{1}^{3}\right]^{\frac{1}{3}}
$$

In order to get the formula of radius $\mathrm{R}_{1}$ change it is required to calculate the change in $\mathrm{R}_{2}$ depending on $\mathrm{R}_{1}$ :

$$
\frac{d R_{2}}{d t}=\frac{d R_{2}}{d R_{1}} \frac{d R_{1}}{d t}=\frac{R_{1}^{2}}{\left(\frac{3 V_{l}}{4 \pi}+R_{1}^{3}\right)^{\frac{2}{3}}} \frac{d R_{1}}{d t}
$$

Combining equations (22), (24) and (25), we get the equation for the pore growth:

$$
\frac{d R_{1}}{d t}=\frac{\frac{3 V_{l}}{4 \pi}+R_{1}^{3}}{4 \mu \frac{3 V_{l}}{4 \pi}}\left(\Delta p R_{1}-2 \sigma\right),
$$

where

$$
\Delta p=p_{\text {int }}-p_{\text {ext. }} .
$$

The Runge-Kutta fourth-order method [1] in the MathCAD program was used for calculations and equation graphical interpretation (26).

Four function values for two intermediate points were used on the following step: two values in the center of the step and the two values at the ends of the step:

$$
\begin{gathered}
\mathrm{k}_{1}=\mathrm{h} \cdot f\left(t_{\mathrm{i}}, R_{\mathrm{i}}\right) ; \\
\mathrm{k}_{2}=f\left(t_{\mathrm{i}}+\frac{1}{2} \cdot \mathrm{h}, R_{\mathrm{i}}+k_{1} \cdot \frac{1}{2} \cdot \Delta R_{\mathrm{i}}\right) ; \\
\mathrm{k}_{3}=f\left(t_{\mathrm{i}}+\frac{1}{2} \cdot \mathrm{h}, R_{\mathrm{i}}+k_{2} \cdot \frac{1}{2} \cdot \Delta R_{\mathrm{i}}\right) . \\
\mathrm{k}_{4}=f\left(t_{\mathrm{i}}+\mathrm{h}, R_{\mathrm{i}}+k_{3} \cdot \Delta R_{\mathrm{i}}\right) . \\
R_{\mathrm{i}+1}=R_{\mathrm{i}}+\left(k_{1}+2 k_{2}+2 k_{3}+k_{4}\right) \cdot \frac{1}{6} \Delta R_{\mathrm{i}} .
\end{gathered}
$$

Runge-Kutta fourth-order method was used, as it provides the calculations with required accuracy and is characterized by resistance and possibility of monitoring the error and calculation step change, unlike «Euler», "Adams» and «Predictor-corrector methods».

Calculations results are presented in Fig. 7. 


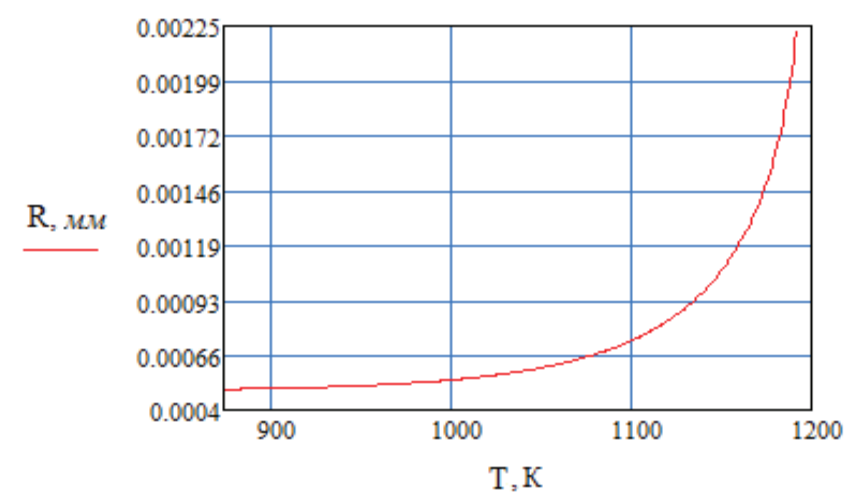

Figure 7. Diagram of pores radius growth depending on the temperature.

Values $\mu$ and $\sigma$ at calculations are taken as variables.

Changing the values of dynamic viscosity was calculated by the formula $[10,18]$ :

$$
\mu=\mu_{0} \cdot 10^{A \cdot \frac{T_{0}-T}{(T-B) \cdot\left(T_{0}-C\right)}}
$$

where $\mu_{0}$ - factor of dynamic viscosity at the initial moment of time $[\mathrm{Pa} \cdot \mathrm{s}], T_{0}-$ temperature at initial moment of time $[\mathrm{K}], \mathrm{T}-$ temperature $[\mathrm{K}]$, $\mathrm{A}$ and $\mathrm{B}-$ empirical factors.

Changing the values of surface tension factor calculated by the formula [21]:

$$
\sigma=\sigma_{0}-0,004 \cdot \frac{T-1173}{100}
$$

where $\sigma_{0}-$ factor of surface tension at the initial moment of time $[\mathrm{N} / \mathrm{m}]$.

Temperature change over time was prescribed as follows:

$$
T=T_{0}+k \cdot t
$$

where $k$ - factor taking into account the heating rate, $\mathrm{t}$ - time [sec].

Value $\mu_{0}$ was taken equal to $10^{10}[\mathrm{~Pa}]$. Value $\sigma_{0}$ was taken equal to $0.2[\mathrm{~N} / \mathrm{m}]$. Factor A was taken equal to 3700 . Factor B was taken equal to 510 . Dynamics of pores radius growth was examined at initial temperature of 293 [K]. Value $k$ was taken equal to 0.25 , which allowed defining the temperature change in increments of $15[\mathrm{~K} / \mathrm{min}]$, that is, we have been simulating total froth building process within 1 hour.

The diagram (Fig. 7) shows that the pore radius starts to increase when the temperature reaches 900 [K], herewith the temperature increase up to $1000[\mathrm{~K}]$ leads to radius increase only by 0.0001 $[\mathrm{m}]$. However, the active melting of glass particles starts at temperatures above 1000 [K], while concentration and pressure of the gas developing agent becomes sufficient for overcoming surface tension forces, and the pore radius starts to increase. When reaching temperatures of 1200 [K] the pore radius increases to the sizes 2-2.5 [mm], after which pore radius growth slows down and then stops. This fact is due to a number of reasons. First, the formed pores start to collapse, as the glass cladding does not withstand high pressures that occur inside and outside the pores due to decrease of surface tension ratio and decrease of viscosity of raw material mixture glass particles (foam glass charge stock). Second, as a result of prolonged exposure to temperatures above $1200[\mathrm{~K}]$, complete thermal decomposition of the gas developing agent takes place, and its amount gradually becomes not sufficient for the new pores formation. The formed pores start to collapse, which ultimately can lead to deterioration of final thermos-physical properties of the finished material.

\section{CONCLUSIONS}

Equation (26) shows that pressure in a pore $\left(p_{\text {int. }}\right)$ should be by $2 \sigma$ greater than the pressure at the outer boundary $\left(p_{\text {ext }}\right.$. $)$ of a pore in order to form glass cladding around the source of gas developing agent by overcoming the surface tension forces. Increase of viscosity of melt glass particles in raw material mixture slows down the pores radius growth rate. Pressure increase inside a pore depends on several factors, major of which is the mass transfer process of glass melt along a pore surface. For further refinement of the pore growth model it's required to consider not only physical parameters but also chemical reactions occurring during the gas generation on the glass 
cladding / pore boundary, this will enable to obtain results through analytical calculations, at mathematic simulation, as close to the real physical and chemical process as possible.

Absence, at present, of mathematical relationships and physically clear concepts regarding this process inhibits the industry development as a whole, but also directly affects the material cost. Development of adequate mathematical models able to describe the dynamics of porous structure formation of foam glass, taking into account temperatures distribution in the material at all stages of thermal treatment, will allow for comprehensive approach to the technological process of foam glass production, as well as to take into account all the peculiarities of heat and mass transfer in the material.

\section{REFERENCES}

1. Bakhvalov N.S. Chislennye metody (Analiz, Algebra, Obyknovennye Differencial'nye Uravnenija) [Numerical Methods (Analysis, Algebra, Ordinary Differential Equations]. Moscow, Nauka, 1975, 632 pages.

2. Demidovich B.K. Proizvodstvo i Primenenie Penostekla [Foam Glass Production and Application. Minsk, Nauka i Tekhnika, 1972, 304 pages.

3. Kitaigorodskii I.I., Keshishian, T.N. Penosteklo [Foam Glass]. Moscow: Promstroiizdat, 1953, 80 pages.

4. Landau L.D. Lifshits E.M. Teoreticheskaja Fizika [Theoretical Physics]. Moscow, Nauka, 1986, 736 pages.

5. Lotov V.A. Foam Glass Production Based on Natural and Technogeneous Aluminosilicates. // Glass and ceramics, 2011, No. 9, pp. 34-37.

6. Lotov V.A., Krivepkova Ye.V. Kinetics of the Porous Structure Formation in the Foam Glass. // Glass and Ceramics, 2002, No. 3.
7. Lykov A.V. Javlenie Perenosa v Lapilljarno-Poristyh Telah [Transport Phenomenon in Capillary-Porous Bodies]. Moscow, Stroiizdat, 1954, 298 pages.

8. Lotov V.A., Kutugin V.A. Method for Heat-Insulating Material and Charge Stock Producing for its Manufacturing: pat. 2478586 the Russian Federation. / Appl. 30.09.11; publ. 10.04.13, Bull. No. 10.

9. Lotov V.A., Kutugin V.A. Method for Foam Glass and Foam Glass Charge Stock Production for its Manufacturing: pat. 2478587 the Russian Federation. / Appl. 30.09.11; publ. 10.04.13, Bull. No. 10.

10. Sangadiev S.Sh., Munkueva S.B., Sanditov D.S. Opredelenie Parametrov Uravnenija Fogelja-Ful'chera-Tammana Dlja Temperaturnoj Zavisimosti Vjazkosti v Oblasti Perehoda Zhidkost'-steklo [Determination of the Vogel-Fulcher-Tammann Equation Parameters for Viscositytemperature Dependence in the Liquid-Glass Transition Area]. // Bulletin of the Buryat State University, 2009, No. 3, pp. 153-156.

11. Tagantsev D.K. Stekloobraznye Materialy [Glassy Materials]. Saint Petersburg, Saint Petersburg Polytechnic University Publishing House, 2010, 204 pages.

12. Fedosov S.V., Bakanov M.O. Development of Integrated Approach to Mathematic Simulation of Foam Glass Charge Stock Thermal Processing. Part 1. Physical Concepts About the Process. // Bulletin of the Volga State University of Technology. Series: Materials. Designs. Technologies, 2017, No. 2, pp. 95-100.

13. Fedosov S.V., Bakanov M.O. Penosteklo: Osobennosti Proizvodstva, Modelirovanie Processov Teploperenosa i Gazoobrazovanija [Foam Glass: Production Specifics, Heat Transfer and Gas Formation Simulation]. // Academia. Architecture and Construction, No 1, 2015, pp. 108-113.

14. Fedosov S.V., Bakanov M.O., Volkov A.V. et al. Mathematical Model of the Pore Formation Dynamics Owing to Heat Treatment of the Foam Glass Batch. // Journal of 
Higher Educational Establishments. Chemistry and Chemical Technology, 2014, Vol. 57, Ed. 3, pp. 73-79.

15. Fedosov S.V., Bakanov M.O., Nikishov S.N. Variability of Approaches to Mathematic Simulation of Foam Glass Charge Stock Thermal Processing. // Academic Journal Bulletin of BSTU named after V.G. Shukhov, 2017, No. 11, pp. 110-116.

16. Shill F. Penosteklo [Foam glass]. Moscow, Stroiizdat, 1965, 307 pages.

17. Kose S. Study of the Dynamics of Foaming of the Foam Glass. PhD thesis, Swiss Federal Institute of Technology, Zurich, Switzerland, 1981.

18. Lakatos T., Johansson L.-G., Simmingskold B. Viscosity Temperature relation in the Glass System SiO2-A12O3-Na2O-K2O$\mathrm{CaO}-\mathrm{MgO}$ in the Composition Range of Technical Glasses. Glass Technol., 1972, No. 13(3), pp. 88-95.

19. Nemec L., Klouzek J. Modeling of Glass Refining Kinetics Part 1. Single Bubbles. // Ceramics - Silicate, 2003, 1980, Volume 47, Number 3, pp. 81-87.

20. Princen H.M., Aronson M.P., Moser J.C. Highly Concentrated Emulsions, II. Real Systems. The Effect of Film Thickness and Contact Angle on the Volume Fraction in Creamed Emulsions. // J. Colloid. Interface Sci., 1980, Volume 75 Number 1, pp. 246270.

21. Scholze H. Glass Nature, Structure and Properties. Springer - Verlag, Berlin Heidelberg New York, 1988.

22. Subramanian R. S., Chi Bo. Bubble dissolution with Chemical Reaction. // Chem. Eng. Sci., 1980, Volume 35, pp. 2185-2194.

\section{СПИСОК ЛИТЕРАТУРЫ}

1. Бахвалов Н.С. Численные методы (анализ, алгебра, обыкновенные дифференциальные уравнения). - М.: Наука, 1975. $632 \mathrm{c}$.
2. Демидович В.К. Производство и применение пеностекла. - Минск: Наука и техника, 1972. - 304 с.

3. Китайгородский И.И., Кашишян Т.Н. Пеностекло. - М.: Промстройиздат, 1953. $-80 \mathrm{c}$.

4. Ландау Л.Д., Лифшиц Е.М. Теоретическая физика. - М.: Наука, 1986. - 736 с.

5. Lotov V.A. Foam Glass Production Based on Natural and Technogeneous Aluminosilicates. // Glass and ceramics, 2011, No. 9, pp. 34-37.

6. Lotov V.A., Krivepkova Ye.V. Kinetics of the Porous Structure Formation in the Foam Glass. // Glass and Ceramics, 2002, No. 3.

7. Лыков А.В. Явление переноса в капиллярно-пористых телах. - М.: Стройиздат, 1954. - 298 c.

8. Lotov V.A., Kutugin V.A. Method for Heat-Insulating Material and Charge Stock Producing for its Manufacturing: pat. 2478586 the Russian Federation. / Appl. 30.09.11; publ. 10.04.13, Bull. No. 10.

9. Lotov V.A., Kutugin V.A. Method for Foam Glass and Foam Glass Charge Stock Production for its Manufacturing: pat. 2478587 the Russian Federation. / Appl. 30.09.11; publ. 10.04.13, Bull. No. 10.

10. Сангадиев С.Ш., Мункуева С.Б., Сандитов Д.С. Определение параметров уравнения Фогеля-Фульчера-Таммана для температурной зависимости вязкости в области перехода жидкость-стекло. // Вестник Бурятского государственного университета, 2009, Вып. 3, с. 153-156.

11. Таганцев Д.К. Стеклообразные материалы. - СПб.: Издательство Санкт-Петербургского государственного политехнического университета, 2010. - 2014 с.

12. Fedosov S.V., Bakanov M.O. Development of Integrated Approach to Mathematic Simulation of Foam Glass Charge Stock Thermal Processing. Part 1. Physical Concepts About the Process. // Bulletin of the Volga State University of Technology. Series: Materials. Designs. Technologies, 2017, No. 2, pp. 95-100. 
13. Федосов С.В., Баканов М.О. Пеностекло: особенности производства, моделирование процессор теплопереноса и газообразования. // ACADEMIA. Архитектура и строительство, 2015, №1, с. 108113.

14. Fedosov S.V., Bakanov M.O., Volkov A.V. et al. Mathematical Model of the Pore Formation Dynamics Owing to Heat Treatment of the Foam Glass Batch. // Journal of Higher Educational Establishments. Chemistry and Chemical Technology, 2014, Vol. 57, Ed. 3, pp. 73-79.

15. Fedosov S.V., Bakanov M.O., Nikishov S.N. Variability of Approaches to Mathematic Simulation of Foam Glass Charge Stock Thermal Processing. // Academic Journal Bulletin of BSTU named after V.G. Shukhov, 2017, No. 11, pp. 110-116.

16. Шилл Ф. Пеностекло. Производство и применение. - М.: Стройиздат, 1965 -308 c.

17. Kose S. Study of the Dynamics of Foaming of the Foam Glass. PhD thesis, Swiss Federal Institute of Technology, Zurich, Switzerland, 1981.

18. Lakatos T., Johansson L.-G., Simmingskold B. Viscosity Temperature relation in the Glass System SiO2-A12O3-Na2O-K2O$\mathrm{CaO}-\mathrm{MgO}$ in the Composition Range of Technical Glasses. Glass Technol., 1972, No. 13(3), pp. 88-95.

19. Nemec L., Klouzek J. Modeling of Glass Refining Kinetics Part 1. Single Bubbles. // Ceramics - Silicate, 2003, 1980, Volume 47, Number 3, pp. 81-87.

20. Princen H.M., Aronson M.P., Moser J.C. Highly Concentrated Emulsions, II. Real Systems. The Effect of Film Thickness and Contact Angle on the Volume Fraction in Creamed Emulsions. // J. Colloid. Interface Sci., 1980, Volume 75 Number 1, pp. 246270.

21. Scholze H. Glass Nature, Structure and Properties. Springer - Verlag, Berlin Heidelberg New York, 1988.
22. Subramanian R. S., Chi Bo. Bubble dissolution with Chemical Reaction. // Chem. Eng. Sci., 1980, Volume 35, pp. 2185-2194.

Федосов Сергей Викторович, академик Российской академии архитектуры и строительных наук (РААСН), профессор, доктор технических наук, президент Ивановского государственного политехнического университета; 153037, Россия, Ивановская область, г. Иваново, ул. 8 Марта, дом 20; тел. + 7(4932) 32-85-40; факс +7(4932) 37-19-42;

E-mail: fedosov-academic53@mail.ru

Баканов Максим Олегович, кандидат технических наук, начальник кафедры, Ивановская пожарно-спасательная академия Государственной противопожарной службы Министерства Российской Федерации по делам гражданской обороны, чрезвычайным ситуациям и ликвидации последствий стихийных бедствий; 153040 , Россия, Ивановская область, г. Иваново, Строителей пр-кт, 33; тел. +7(4932)34-37-09;

E-mail: mask-13@mail.ru

Никишов Сергей Николаевич, аспирант Ивановского государственного политехнического университета; старший преподаватель кафедры пожарно-строевой, физической подготовки и газодымозащитной службы Ивановской пожарно-спасательной академии ГПС МЧС России; 153040, Россия, Ивановская область, г. Иваново, Строителей пр-кт, 33;

тел. +7(4932)34-37-09; e-mail: mordov5988@mail.ru

Sergey V. Fedosov, Full Member of the Russian Academy of Architecture and Construction Science (RAACS), president of the Ivanovo state Polytechnic University; Ivanovo State Politechnical University; 20, U1. 8 Marta, Ivanovo, 153037, Russia; phone + 7(4932) 32-85-40;

Fax: +7(4932) 37-19-42;

e-mail: fedosov-academic53@mail.ru.

Maxim O. Bakanov, Candidate of technical Sciences, Ivanovo Fire Rescue Academy of State Firefighting Service of Ministry of Russian Federation for Civil Defense, Emergencies and Elimination of Consequences of Natural Disasters; 33, Prospekt Stroiteley, Ivanovo, 153040, Russia; tel. +7(4932)34-37-09; e-mail: mask-13@mail.ru.

Sergey N. Nikishov, Ivanovo Fire Rescue Academy of State Firefighting Service of Ministry of Russian Federation for Civil Defense, Emergencies and Elimination of Consequences of Natural Disasters; 33, Prospekt Stroiteley, Ivanovo, 153040, Russia; tel. +7 (4932)34-37-09; E-mail: mordov5988@mail.ru. 